\title{
THE DEVELOPMENT OF STUDENT'S LEADERSHIP READINESS ASSESSMENT INSTRUMENT IN INDONESIA
}

\author{
Thomas Budi Santoso ${ }^{\varpi}$, Theodorus Sudimin2, and Rudy Elyadi2 \\ 1,2, Universitas Katolik Soegijapranata, Indonesia \\ $\triangle \underline{\text { Thom.santoso@gmail.com, theo@unika.ac.id }}$
}

\begin{abstract}
The objectives of this study were: (a) to validate a research instrument on Indonesian student leadership readiness; (b) to analyze the student leadership readiness, based on the developed instrument; and (c) to describe the student leadership education programs of some universities in Indonesia. Data collection was carried out through two stages. The first stage of data collection is conducting in-depth interviews with resource persons to compile research instruments distributed in the second stage of data collection. The second stage of data collection was in the form of distributing questionnaires to 1,742 respondents. By using factor analysis, this study succeeded in compiling a research instrument named Student's Leadership Readiness Questionnaire (SLRQ). Ultimately, by employing, the analysis of Pearson Product Moment and Cronbach Alpha, the present paper found that the design of the research instrument on student leadership readiness must first be adjusted. That is, some statement items that are declared invalid are excluded from the design of the research instrument so that the number of question items that were originally 25 statement items was reduced to 18 items. The study found as well that the average student leadership readiness in the universities involved in the study was to be high. Meanwhile, the study found that various programs are constituted as an integral part of the leadership education program. Nevertheless, it is necessary to carry out a more effective leadership education design, especially the integration of academic activities, co-curricular activities, and extra-curricular activities in an integrated manner as a whole unit of Indonesian student leadership education.
\end{abstract}

Keywords: student's leadership readiness; student leadership education program.

\section{INTRODUCTION}

Data published by Development Dimensions International (DDI) shows that from 2011 to 2014 the ability of the Indonesian nation to fill future bench strengths experienced a proud increase compared to the other three ASEAN countries, namely: Thailand, Malaysia, and the Philippines (DDI, 2014; DDI, 2015). However, behind that pride, there are still some concerns because it is stated that the quality of organizational leadership that is currently (current leader quality) has not been as expected, especially in the face of extraordinary environmental changes and developments. From the same source, it is stated that most organizational leaders in Indonesia are not all capable or slightly capable in facing rapid, uncertain and complex environmental changes; consequently, efforts to prepare future leaders should be made early (Kouzes \& Posner, 2008; Welch et al, 2014).

In an era that is changing fast, uncertain, and complex leaders are demanded more than just having a certain character, leaders are required to play an important role in making changes and organizational development, because they are the change agents as well as the change masters, namely the right people, think and act appropriately (Kanter, 1983; Johansen, 2010; Lawrence, 2013; Keating et al, 2014; Mack \& Khare, 2016), at the right time, in the right position, and in the right circumstances and conditions to make changes and organizational development so that the organizations they lead are not 'swept away' or 'drowned' swallowed by changes and development in the environment (Bolman \& Deal, 2015). In such an era, organizations in Indonesia, 
including government institutions, need future leaders who are not just leaders who have the character of honesty, loyalty, sincerity, discipline, commitment, and high dedication; not also a leader who is only able to face the challenges of changing times, but a leader who also has: (a) agility to develop self-mind and ability, or 'learn', to have more comprehensive thinking, capable strategic thinking to develop the organization; (b) mental models (paradigm, mindset, vision, outlook) that are flexible, adaptive, sensitive, and instinctive towards various forms of environmental change and development; and (c) being able to turn 'dilemmas' into opportunities. In short, it can be said that organizations in Indonesia need leaders who are capable of 'acrobatic' in a nimble, strategic and professional manner in the future (Hannah \& Avolio, 2010; Lawrence, 2013; Leonard, 2016).

The first question that needs to be addressed is: "is the right leader in the need to be prepared?" There is an opinion that states that leadership is a gift of God that is naturally bestowed from birth, then is the most appropriate answer is only God is omniscient who knows the truth? But there are some respondents argue that leadership arises because of someone's extraordinary learning outcomes, including learning from experience and training from environmental situations and conditions, so the most appropriate answer is that leadership should be prepared. Leadership capability develops through a process, namely education, training, and experience. As an art and science, management accommodates these two principles: "When someone has a leadership gift and is honed through education, training, and experience, then that person will have great leadership capabilities, but when the gift is left alone, then the gift will slow to develop or can even stop at a certain point of capability" (Hezlet, 2016; Lawrence, 2013).

The second question is: "who is responsible for preparing the right leaders in the coming era?" Ideally, those responsible for preparing leaders in the future are every citizen of Indonesia, at least have moral responsibility. However, higher education institutions and training institutions for adults (adult learners) in charge of organizational leadership should have a greater responsibility than moral responsibility, because they are also demanded by scientific responsibility, methodological responsibility, and responsibility. technical in preparing leaders. The third question is reflective: "have our educational institutions participated morally, scientifically, technically and methodologically to be able to prepare for the presence of leaders who are capable of 'acrobatic' nimble, strategic and professional in the coming era?" education managers, academics, widyaiswara, trainers and leadership practitioners (Hamid \& Krauss, 2013).

This research is based on the logical and idealistic premise above, where the readiness of leadership of students should be prepared through various programs. Some tertiary institutions have done it through several levels of leadership training. Furthermore, this study aims to (a) conduct a test of student leadership readiness instruments developed by a research team (Santoso et al, 2018), and (b) conduct leadership readiness analysis based on an instrument.

\section{METHOD}

This research is descriptive exploratory and development research (especially the development of research instruments). In this study, the researchers determined the research locations in the City of Semarang and the City of Yogyakarta. Specifically, the research location was focused on 9 (nine) universities. , namely: (1) SCU, (2) MUS, (3) SAIU, (4) SU, (5) SSU, (6) SDU, (7) DWCU, (8) STU, and (9) YSU.

The selection of universities is based on the following categories: (a) representatives of religion-based private universities, (b) representatives of non-religious based private universities, and (c) representatives of state universities. The population of this study is student activists at the established university those are the students that affiliate in the so-called ORMAWA (Organisasi Kemahasiswaan). 
All the data used in this study are primary. Data collection is carried out through two stages. The first stage is distributing questionnaires to students at the universities involved. The second stage of data collection was in the form of focus group discussions (FGD) involving student activists at the universities involved. In the first stage, the research team collects 1,742.

The technique of analysis used in this study is descriptive analysis, both quantitative and qualitative. In the quantitative context, this study validates the instrument using the analysis of Pearson Product Moment and Cronbach Alpha. In the context of qualitative analysis carried out using content analysis based on data obtained from the field about student leadership readiness.

\section{RESULTS}

Three parts will be discussed in this subchapter, namely: validity test, reliability test, and factor analysis to find out the component of 'leadership readiness'.

\section{Validity and reliability test.}

This study tested the validity of using bivariate Pearson correlation (Pearson Product Moment) and Cronbach Alpha reliability test. The number of cases is 1,472 by choosing a significance level of $5 \%$. In the first test, there is an invalid item (KK21) because the calculated $r$-value is smaller than $r$ table (0.039). Of the 25 validated items, only 24 items are valid in this first stage validity test. For the next validity test, the KK21 item is not included in the validity test (omitted). The value of reliability in the first stage of the test is 0.812 (reliable).

In the validity and reliability test, the second stage had 24 items tested. The results of the second stage of the validity test showed that there were two invalid items (KK13 and KK 17) because the calculated $r$-value was smaller than the $r$ table (0.039), so there are only 22 items. Therefore for the next validity test, items KK 13 and KK 17 are not included in the validity test (omitted). The value of reliability in the second stage test, after items KK13 and KK17 are omitted, this is 0.825 (reliable). The third stage of validity and reliability tests was conducted to test the remaining 22 items. The third validity and reliability test results show that there are
3 (three) invalid items, namely KK 11, KK 12, and KK 15; so that only 19 valid items are declared valid in the third stage validity and reliability test. For the next test, the fourth stage of validity and reliability, the three variables (KK11, KK12, and KK15) are not included (the calculated $r$-value is smaller than r-able. The reliability value in the third stage of the test is 0.849 (reliable)

In the validity and reliability test, the second stage had 24 items tested. The results of the second stage of validity test showed that there were two invalid items (KK13 and KK 17) because the calculated r-value was smaller than r-table (0.039); so there are only 22 items. Therefore for the next validity test, items KK13 and KK17 are not included in the validity test (omitted). The value of reliability in the second stage test, after items KK13 and KK17 are omitted, this is 0.825 (reliable). The third stage of validity and reliability tests was conducted to test the remaining 22 items. The third validity and reliability test results show that there are 3 (three) invalid items, namely KK11, KK 12, and KK 15; so that only 19 valid items are declared valid in the third stage validity and reliability test. For the next test, the fourth stage of validity and reliability, the three variables (KK11, KK 12, and KK15) are not included (the calculated r-value is smaller than the $r$ table. The reliability value in the third stage of the test is 0.849 (reliable).

The fourth stage of validity and reliability testing is done to ensure that the remaining 19 items are all valid. In testing the validity of the fourth stage, it turns out there is still an item that is declared invalid (KK14). The value of reliability in this fourth stage test, after the KK14 item is omitted, rises to 0.889 (reliable).

The fifth stage of validity and reliability testing is done to ensure that the remaining 18 items are all valid. In the fifth stage validity test, it turns out that all items are declared valid. The reliability value in this fifth stage test, after the KK14 item is not included in the test, rises to 0.903 (reliable).

Based on the validity and reliability tests that have been carried out, the design of the research instrument on student leadership readiness must first be adjusted. That is, some statement items that are 
declared invalid are excluded from the design of the research instrument so that the number of question items that were originally 25 statement items was reduced to 18 item statements.

Furthermore, to find out that the instrument on student leadership readiness consists of how many components it forms, or the dimensions forming the instrument, factor analysis is carried out. The following factor analysis is the last instrument test step in this study.

The purpose of this factor analysis is to identify relatively small factors to explain leadership preparedness variables (Hidayat, 2014); or, in other words, to obtain the components or "dimensions of variable leadership formation or explanation for student leadership readiness". The first step is to do factor analysis and see the results of the analysis, especially by looking at the value of Kaiser Meyer-Oklin (KMO) Measure of Sampling Adequacy and Barlett test of sphericity, namely the correlation matrix between items.

Based on the calculation of Kaiser MeyerOklin (KMO) Measure of Sampling Adequacy and Barlett test of sphericity values above, it can be stated that factor analysis can be continued because of the level of sample adequacy (MSA) is greater than 0.5 . This is also reinforced by the antiimage value of each item above 0.5 (Table $2)$, the 18 items from the fifth stage of validity and reliability (Table 1) have an anti-image value above the number 0.5 . This means that the 18 items can be included in the next stage of analysis, which is an analysis to determine the possibility of the possible number of factors formed from 18 item statements.

Furthermore, to show that the possible number of factors formed from the 18 statement items in the table above, the research team used the Total Variance Explained (Table 3). Based on the table, it is known that the components that can be formed are components that have a total Eigenvalues greater than 1 (> 1). Therefore, there are three possible factors, namely: component 1, component 2, and component 3.
The three components formed can be known from the Rotated Component Matrix formed. Rotated Component Matrix shows how much a component correlates with items of observation (loading factor). The value of the loading factor ranges from 0 to 1 , and in this study, the value of the loading factor that is determined as 'forming' a component (or factor) is the value of the loading factor above the value of 0.5 .

Based on these stipulations, some component forming components (or factors) in this study are shown in Table 5, where: (a) there are 8 (eight) items forming component 1, namely: KK04, KKO1, KK07, KK10, KK19, KK02, KK20, and KK03. (b) there are 3 (three) items forming component 2 , namely: KK05, KK09, and KK06. (c) there are 4 (four) items forming component 3, namely: KK24, KK23, KK25, KK. In Table 4 there are still three items (KK08, KK18, and KK16) which have some loading factors of less than 0.5. Therefore, to ensure that component 1, component 2, and component 3 are formed from the items mentioned above, items KK08, KK18, and KK 16 are omitted in the next analysis.

Based on the review of the literature and the discussions conducted in the team, the study found three components of the instrument that was named according to the contents of the items referred to. Those three components found in the study are (1) Knowledge and Skill Readiness, (2) Mental Readiness and Social Interaction, and (3) Readiness of Desire and Openness. These three components can then be understood as indicators to measure leadership readiness.

\section{Leadership education programs}

Most leadership education in higher education is done through leadership training either conducted by the university or by the faculty. The leadership training conducted by universities included the Basic Leadership Training (LKD) or the Basic Leadership Training (LKTD) and Advanced Leadership Training (LKTL). The leadership 
training that is carried out by faculty is Leadership and Student Management Training (LKMM), Scout Leadership Training, Paskibraka Leadership Training, and Menwa Leadership Training. As activists, all respondents should attend the training, some of the respondents had even attended training between 3 to 5 times. Nevertheless, some of them say 'not useful', some even say 'do not know' the benefits of the training followed.

The leadership education they received was more in the form of leadership training. Respondents' responses to the benefits of the training they participated in were'beneficial' although some of them stated that 'they did not know the benefits of the training they had participated in' or some even stated that the training they participated in was not useful. There are various reasons given by respondents to the leadership education program in their colleges. Some of them stated that the resource persons were not competent, the seriousness of the students who were low when attending the training, the atmosphere of the training that was not supportive, the training facilities that did not meet the requirements, and the lack of follow-up of the training conducted.

Besides, according to the respondents' testimonies, several courses are considered to have a role as courses that have high leadership education content. Nevertheless, there is a small number of respondents (1.98\%) who do not provide answers to questions: "What subjects do you think have leadership education content?" Based on this recognition, it is necessary to design a leadership education model for students in their respective colleges, one of which is curriculum design for certain subjects which are considered to have an important role to improve student leadership readiness in the future.

One of the interesting things is that several courses are often viewed as 'trivial' but have an effective leadership education content. Therefore, to improve the leadership readiness of students, curriculum design for certain subjects, such as Citizenship Education, Entrepreneurship Education, Professional Management, Pancasila Education, and several other courses should be taken seriously by the management of higher education as a strategic course to improve student leadership readiness.

One of the things that would become a barrier is the existence of several courses ignored by students. As an effective course as a subject which is also a course in leadership education, it is sometimes seen as 'summarized' by students because students prioritize educational programs that are more 'hard-skills' than 'soft-skills'.

This finding will be very important if one of the higher education missions is to improve student leadership readiness: ing ngarsa sung tuladha, madya mangun karsa, and tut wuri handayani; leadership trilogy taught by the Father of Indonesian Education, Ki Hadjar Dewantara (Moelyono, 2003).

\section{Students Leadership Readiness}

This subsection answer the third research question, which aims to describe student leadership readiness in nine universities in the City of Semarang and the City of Yogyakarta. Overall, student leadership readiness in the nine universities involved in the study was in the high category (Table 3). When viewed from the three components formed from the 18 items of leadership readiness (readiness of knowledge and skills, moral readiness and social interaction, and readiness for desire and openness), the three have scores that fall into the high category. That is, these conditions indicate that: (a) respondent respondents 'confidence in their competence and ability to become successful and whole-hearted leaders for future organizations/institutions is in the high category'. Even one of the three components of the Student Leadership Readiness Instrument, that is the Moral Readiness and Social Interaction has a very high score for all the universities. The third component, however, that is the Desire and Openness Readiness, constitutes the weakest component. This means that the desire to become a leader who has openness needs attention in leadership education at these universities is relatively weak.

\section{DISCUSSION}

The word 'readiness' in this study refers to the notion: "preparedness of persons to meet the situation and carry out a planned 
sequence of actions" (http://www.businessdictionary.com). The word is also understood as: the degree of preparedness to act or to respond to a particular stimulus" (https: // psychology dictionary. org). Zainab \& Baig (2011: 91-95) state that 'leadership readiness' is a very old 'concept', however, research on leadership readiness is still very rarely done. Among several experts, Avolio and Hannah are the two main researchers involved in research on leadership readiness development (Hannah \& Avolio, 2010).

In the present and the future, leadership readiness is increasingly needed because environmental conditions will still change, even change quickly and difficult to predict its direction. That is, future leaders are not only leaders who can face the challenges of change and future developments, but also (a) leaders who have the agility to think comprehensively, think strategically, and have high adaptability to change; (b) leaders who have mental models (paradigms, mindsets, visions, views on global developments) that are flexible and have a high sensitivity to environmental change and development; (c) an instinctive leader (maker instinct); have clarity about what they make but are very flexible about how they get it (clarity); able to turn 'dilemmas' into profits and opportunities; have the ability to learn indepth and others (Johansen, 2010; Lawrence, 2013; Petrie, 2014; Bolman \& Deal, 2015

Some authors state that leadership readiness is a situation or condition related to (a) various efforts to prepare leaders for tomorrow which are carried out today, (b) explore and develop leadership talents for tomorrow in an innovative way, (c) the process of identifying and developing future generations of leaders, (d) developing the skills, abilities, and insights that are most needed by future leaders to ensure future performance, and (e) preparation for becoming leaders who are ready to emerge or ' present 'to face various opportunities in the future (Williams \& Cothrel, 1997; Hamid \& Krauss, 2013; Bergelson, 2014). Zainab \& Baig (2011) states that ability, willingness is the main components needed to measure leadership readiness; Furthermore, Zainab \& Baig emphasized that abilities include aspects of knowledge, experience, training, and understanding; while the willingness (willingness) includes three aspects: the will (desire), confidence (confidence), and commitment (commitment). However, several other authors (Bouffard \& Savitz-Romer, 2012; Keating et al., 2014; Rivas \& Jones, 2015) state that leadership readiness is an integral part of leadership capability, in which leadership capability includes three aspects referred to as possession of leadership self-efficacy ("ready"), exhibition of motivation to lead ("willing"), and possession of leadership skill ("able"). In other words, leadership capabilities include one's readiness, willingness, and ability to lead an organization.

This research was inspired by the thoughts of Hannah \& Avolio (2010) about the concept of leadership development which includes: goal-oriented learning; development efficacy; leader complexity; and meta-cognitive ability. This study was also inspired by previous research (Santoso et al, 2018) in which found that the average leadership readiness of students included in the category of slightly high. In other words, learning goal-oriented); development efficacy); leader complexity; and metacognitive ability of students when students must appear as future leaders in the less high category. Furthermore, the research proposes four important things, namely: (a) the need to develop research instruments on the readiness of Indonesian student leadership; (b) the effectiveness of leadership education in tertiary institutions; and (c) further studies to determine the effectiveness of leadership education in tertiary institutions.

The research instrument serves as a tool for researchers in terms of collecting data needed in their research. Therefore, research instruments related to data collection methods, including interview methods; survey methods; observation methods, and so on. The format of the questionnaire is very diverse, such as a) an open questionnaire in which the 
respondent is free to answer in his sentence, in the same form as the questionnaire. b) closed questionnaire where the respondent only chooses the answer provided, the form is the same as a multiple-choice questionnaire c) direct questionnaire where the respondent answers questions about him d) indirect questionnaire where the respondent answers questions relating to others e) checklist in the form of a closed questionnaire, the respondent only needs to put a checkmark in the column of available answers f) multilevel scale where the respondent is equipped with multilevel statements, usually showing a scale of attitudes that range from strongly agree to strongly disagree to his statement. The research instrument on "Student Leadership Readiness" is the output of a series of studies conducted by Santoso and his colleagues (2017; 2018) which began with explorative studies and continued with factor analysis and trial instruments for validation. Based on the factor analysis, this instrument consists of four (4) dimensions, namely: (a) (Moral and Knowledge Dimension, (b) Empathy and Experience Dimension, (c) Passion and Exemplary Dimension, and (d) Personal Openness and Mission Dimension Each dimension consists of several different items in line with recommendations from the factor analysis conducted (Santoso et al., 2017; 2018). Furthermore, the research team gave the name of the Indonesian Student Leadership Readiness Questionnaire (SLRQ) that consist which consisted of 25 items and 4 (four) dimensions.

To conduct a validity test, the present study uses a Bivariate Pearson correlation (Pearson's Moment Product). This analysis is by correlating each item's score with the total score. The total score is the sum of all items. Question items that correlate significantly with the total score indicate that these items can provide support in uncovering what you want revealed à Valid. If $r$ arithmetic $\geq r$ tables (2-sided test with sig. 0.05) then the instrument or question items correlate significantly to the total score (declared valid). Meanwhile, to test the reliability of the instrument, this study uses the Cronbach Alpha; if Alpha> 0.7 means that reliability is sufficient while Alpha $>0.80$ suggests all items are reliable and all tests consistently have strong reliability. Based on the validity and reliability tests that have been carried out, research instruments on student leadership readiness should be improved because there are seven items declared invalid. After the seven items were excluded from the research instrument so that the number of question items which were originally 25 statement items was reduced to 18 statement items, the final results became valid and reliable (Alpha $=$ r-table for 1,472 cases $=0.039$ and Cronbach's alpha reliability $=0.903$ )

Unfortunately, this work described in this present paper contributes to the research of the existing classroom environment in the following ways: (a) Research in the previous stage uses EFA employed CFA as well as EFA to examine the construct validity of this newly-developed instrument. This crossvalidation work ensures the generalisability of this instrument, and provides support for the degree to which the measurement model fits the actual data collected about tertiary students' perceptions using survey questionnaire; (b) This study recommends that the instruments on Student Leadership Readiness be refined to be reliable and valid for measuring future student leadership readiness from tertiary institutions, especially in Indonesia, due to the lack of research instruments on student leadership readiness (Santoso et al, 2017).

\section{CONCLUSION}

Based on the analysis and discussion carried out, the research team addressed the following conclusions:

1. Based on the validity and reliability tests conducted, this study found that the research instrument on leadership readiness named: STUDENT'S LEADERSHIP READINESS QUESTIONNAIRE (SLRQ) is valid and reliable.

2. There are various forms of leadership education that have been carried out in nine universities in the City of Semarang and Yogyakarta, mainly in the form of leadership training. Nonetheless, some respondents stated that the training they attended was not useful. Therefore there is a need for a comprehensive design of student leadership education in Indonesia. 
3. Description of 'student leadership readiness' in five tertiary institutions in the city of Semarang, on average stated high. Nevertheless, certain items are still in the low category. The item is one element of the 'Empathy and Experience' dimension, as well as the 'Desire and Experience' dimension. Hopefully, these two dimensions become dimensions that need to be considered in this study. Besides, many courses are considered by the respondents as subjects that have high leadership education content, for example, Citizenship course, Entrepreneurship Education, Pancasila Education and so on. That is, student leadership education can also involve academic activities that are curricular based.

\section{REFERENCES}

Bolman, L. G., \& Deal, T. E. (2015). Think-or sink: Leading in a VUCA world. Leader to Leader, 2015(76), 35-40.

Bouffard, S. M., \& Savitz-Romer, M. (2012). Ready, Willing, and Able. Educational Leadership, 69(7), 40-43.

DDI. (2014). Indonesia ready-now leaders: meeting tomorrow's business challenges. Downloaded from: http://www.ddiworld.com/DDI/ media/trend-research/globalleadership-forecast-2014indonesia_tr_ddi.pdf?ext=.pdf

DDI. (2015). Indonesia ready-now leaders: meeting tomorrow's business challenges. Downloaded from: http://www.ddiworld.com/DDI/ media/trend-research/globalleadership-forecast-2015indonesia_tr_ddi.pdf? ext=.pdf

Hannah, S. T., \& Avolio, B. J. (2010). Ready or not: How do we accelerate the developmental readiness of leaders?. Journal of Organizational Behavior, 31 (8), 1181-1187.

Hamid, J. A., \& Krauss, S. E. (2013). Does university campus experience develop the motivation to lead or readiness to lead among undergraduate students? a Malaysian perspective. Journal of Student Affairs Research and Practice, 50 (2), 208-225.

Hezlett, S. A. (2016). Enhancing experiencedriven leadership development. Advances in Developing Human Resources, 18(3), 369-389.

Johansen, B. (2010). Leaders will make the future of aging. Generations, 34(3), 20-22.

Kanter, R. M. (1983). Change masters and the intricate architecture of corporate culture change. Management

Review, 72(10), 18-28.

Keating, K., Rosch, D., \& Burgoon, L. (2014). Developmental Readiness for Leadership: The Differential Effects of Leadership Courses on Creating" Ready, Willing, and Able" Leaders. Journal of Leadership Education, 13(3).

Lawrence, K. (2013). Developing Leaders in a VUCA environment. UNC Executive Development, 1-15.

Leonard, D. (2016). The future of quality: strategy, leadership and an opportunity to improve quality of life on a global scale there to be seized or lost. Naskah dalam Sampaio, P \& Saraiva, P (eds), Quality in the 21st Century. New York: Springer International Publishing.

Mack, O., \& Khare, A. (2016). Perspective in VUCA. In Mack et al. (eds), Managing in a VUCA World. New York: Springer International Publishing.

Moelyono, D. (2003). Beyond Leadership: 12 Konsep Kepemimpinan. Jakarta: Elex Media Komputindo.

Rivas, O., \& Jones, I. S. (2015). Investing in Yourself: One University's Leadership Models. Research in Higher Education Journal, 27.

Santoso, T.B., Elyadi, dan Sudimin,T. (2018). Pengembangan instrumen dan analisisi kesiapan kepemimpinan mahasiswa: implikasinya terhadap pendidikan kepemimpinan di perguruan tinggi. Unpublished Research Report. 
Welch, D., Grossaint, K., Reid, K., \& Walker, C. (2014). Strengths-based leadership development: Insights from expert coaches. Consulting Psychology Journal: Practice and Research, 66(1), 20.
Williams, R. L., \& Cothrel, J. P. (1997). Building tomorrow's leaders today. Strategy \& Leadership, 25(5), 17-22.

http://www.businessdictionary.com

http: // psychologydictionary. org

\section{APPENDICES}

\section{Table 1. THE FIRST STEP VALIDITY AND RELIABILITY TEST}

\begin{tabular}{|c|c|c|c|c|c|}
\hline \multicolumn{6}{|c|}{ Item-Total Statistics } \\
\hline Items & $\begin{array}{l}\text { Scale Mean if } \\
\text { Item Deleted }\end{array}$ & $\begin{array}{l}\text { Scale Variance } \\
\text { if Item Deleted }\end{array}$ & $\begin{array}{c}\text { Corrected Item- } \\
\text { Total } \\
\text { Correlation }\end{array}$ & $\begin{array}{l}\text { Squared } \\
\text { Multiple } \\
\text { Correlation }\end{array}$ & $\begin{array}{c}\text { Cronbach's } \\
\text { Alpha if Item } \\
\text { Deleted }\end{array}$ \\
\hline KKOI & 82.5987 & 69.220 & .527 & .506 & .757 \\
\hline KKO2 & 82.6332 & 70.777 & .429 & .401 & .763 \\
\hline KKO3 & 82.5471 & 70.168 & .449 & .424 & .761 \\
\hline KKO4 & 82.8651 & 68.567 & .517 & .444 & .757 \\
\hline KK05 & 82.4282 & 71.520 & .342 & .307 & .766 \\
\hline KK06 & 82.3823 & 70.895 & .345 & .299 & .766 \\
\hline KKO7 & 82.9173 & 68.394 & .490 & .371 & .757 \\
\hline KK08 & 82.8404 & 69.269 & .436 & .343 & .760 \\
\hline KK09 & 82.2382 & 71.483 & .320 & .337 & .767 \\
\hline KK10 & 82.6975 & 69.424 & .495 & .454 & .759 \\
\hline KK11 & 83.8651 & 72.701 & .123 & .306 & .780 \\
\hline KK12 & 84.2285 & 72.931 & .105 & .408 & .782 \\
\hline KK13 & 84.1412 & 73.947 & .059 & .434 & .784 \\
\hline KK14 & 84.5534 & 70.799 & .173 & .454 & .780 \\
\hline
\end{tabular}

Table 1. Continued 


\begin{tabular}{llllll}
\hline KK15 & 84.5907 & 72.205 & .151 & .518 & .778 \\
KK16 & 82.6929 & 70.259 & .376 & .366 & .764 \\
KK17 & 83.6401 & 73.874 & .061 & .224 & .784 \\
KK18 & 82.7417 & 69.756 & .444 & .441 & .761 \\
KK19 & 82.7428 & 69.268 & .494 & .464 & .758 \\
KK20 & 82.6757 & 68.928 & .498 & .422 & .758 \\
KK21 & 83.9259 & 75.630 & -.029 & .343 & .788 \\
KK22 & 82.7262 & 69.229 & .455 & .397 & .760 \\
KK23 & 83.1464 & 70.562 & .296 & .196 & .768 \\
KK24 & 82.5758 & 70.972 & .306 & .235 & .768 \\
KK25 & 82.8042 & 68.874 & .480 & .452 & .758 \\
\hline
\end{tabular}

Source: Primary Data, processed 2019.

Reliability Alpha Cronbach $=0,812$

$r$ tabel for 1.472 cases $=0,039$.

Table 2. THE SECOND STEP VALIDITY AND RELIABILITY TEST

\begin{tabular}{cccccc}
\hline \multicolumn{5}{c}{ Item-Total Statistics } \\
\hline Items & $\begin{array}{c}\text { Scale Mean if } \\
\text { Item Deleted }\end{array}$ & $\begin{array}{c}\text { Scale Variance } \\
\text { if Item Deleted }\end{array}$ & $\begin{array}{c}\text { Corrected Item- } \\
\text { Total } \\
\text { Correlation }\end{array}$ & $\begin{array}{c}\text { Squared } \\
\text { Multiple } \\
\text { Correlation }\end{array}$ & $\begin{array}{c}\text { Cronbach's } \\
\text { Alpha if Item } \\
\text { Deleted }\end{array}$ \\
\hline KK01 & 79.9747 & 68.384 & .561 & .503 & .770 \\
KK02 & 80.0092 & 70.034 & .456 & .400 & .776 \\
KK03 & 79.9231 & 69.451 & .473 & .422 & .774 \\
KK04 & 80.2411 & 67.796 & .543 & .444 & .770 \\
KK05 & 79.8042 & 70.855 & .360 & .306 & .779 \\
KK06 & 79.7583 & 70.252 & .361 & .297 & .779 \\
KK07 & 80.2933 & 67.667 & .512 & .371 & .771 \\
KK08 & 80.2164 & 68.515 & .459 & .343 & .773 \\
\hline
\end{tabular}


Table 2. Continued

\begin{tabular}{|c|c|c|c|c|c|}
\hline KK09 & 79.6142 & 70.797 & .340 & .336 & .780 \\
\hline KK 10 & 80.0735 & 68.593 & .528 & .453 & .771 \\
\hline KK11 & 81.2411 & 73.053 & .078 & .289 & .797 \\
\hline KK12 & 81.6045 & 73.205 & .065 & .406 & .798 \\
\hline KK13 & 81.5172 & 74.367 & .010 & .422 & .800 \\
\hline KK 14 & 81.9294 & 71.126 & .135 & .452 & .797 \\
\hline KK15 & 81.9667 & 72.573 & .105 & .511 & .795 \\
\hline KK16 & 80.0689 & 69.408 & .407 & .364 & .776 \\
\hline KK17 & 81.0161 & 74.136 & .021 & .209 & .800 \\
\hline KK 18 & 80.1177 & 68.964 & .472 & .441 & .774 \\
\hline KK19 & 80.1188 & 68.428 & .527 & .462 & .771 \\
\hline KK20 & 80.0517 & 68.143 & .525 & .422 & .771 \\
\hline KK22 & 80.1022 & 68.388 & .485 & .396 & .772 \\
\hline KK23 & 80.5224 & 69.922 & .309 & .196 & .781 \\
\hline KK24 & 79.9518 & 70.337 & .319 & .234 & .781 \\
\hline KK25 & 80.1803 & 67.992 & .514 & .448 & .771 \\
\hline
\end{tabular}

Source: Primary Data, processed 2019.

Reliability Alpha Cronbach $=0,25$

r tabel for 1.472 cases $=0,039$.

Table 3. THE THIRD STEP VALIDITY AND RELIABILITY TEST

\begin{tabular}{cccccc}
\hline \multicolumn{5}{c}{ Item-Total Statistics } \\
\hline Items & $\begin{array}{c}\text { Scale Mean if } \\
\text { Item Deleted }\end{array}$ & $\begin{array}{c}\text { Scale Variance } \\
\text { if Item Deleted }\end{array}$ & $\begin{array}{c}\text { Corrected Item- } \\
\text { Total } \\
\text { Correlation }\end{array}$ & $\begin{array}{c}\text { Squared } \\
\text { Multiple } \\
\text { Correlation }\end{array}$ & $\begin{array}{c}\text { Cronbach's } \\
\text { Alpha if Item } \\
\text { Deleted }\end{array}$ \\
\hline KK01 & 74.6561 & 65.862 & .619 & .499 & .798 \\
KK02 & 74.6906 & 67.638 & .503 & .400 & .803 \\
KK03 & 74.6045 & 66.948 & .527 & .421 & .802 \\
\hline
\end{tabular}


Table 3. Continued

\begin{tabular}{|c|c|c|c|c|c|}
\hline KKO4 & 74.9225 & 65.420 & .584 & .444 & .798 \\
\hline KK05 & 74.4856 & 68.475 & .402 & .305 & .807 \\
\hline KKO6 & 74.4397 & 67.905 & .396 & .295 & .807 \\
\hline KK07 & 74.9747 & 65.294 & .550 & .369 & .799 \\
\hline KK08 & 74.8978 & 66.034 & .505 & .341 & .802 \\
\hline KKO9 & 74.2956 & 68.367 & .383 & .335 & .808 \\
\hline KK 10 & 74.7549 & 66.102 & .581 & .452 & .799 \\
\hline KK11 & 75.9225 & 72.731 & -.012 & .253 & .831 \\
\hline KK 12 & 76.2859 & 73.114 & -.035 & .336 & .833 \\
\hline KK 14 & 76.6108 & 70.968 & .051 & .446 & .832 \\
\hline KK15 & 76.6481 & 72.445 & .004 & .489 & .830 \\
\hline KK 16 & 74.7503 & 66.853 & .458 & .363 & .804 \\
\hline KK 18 & 74.7991 & 66.475 & .521 & .440 & .801 \\
\hline KK 19 & 74.8002 & 66.013 & .573 & .461 & .799 \\
\hline KK20 & 74.7331 & 65.690 & .573 & .420 & .799 \\
\hline KK22 & 74.7836 & 65.887 & .534 & .394 & .800 \\
\hline KK23 & 75.2038 & 67.764 & .326 & .192 & .810 \\
\hline KK24 & 74.6332 & 68.083 & .344 & .227 & .809 \\
\hline KK25 & 74.8617 & 65.456 & .567 & .447 & .799 \\
\hline
\end{tabular}

Source: Primary Data, processed 2019.

Reliability Alpha Cronbach $=0,849$

r tabel for 1.472 cases $=0,039$. 
Table 4. THE FOURTH STEP VALIDITY AND RELIABILITY TEST

\begin{tabular}{|c|c|c|c|c|c|}
\hline \multicolumn{6}{|c|}{ Item-Total Statistics } \\
\hline Items & $\begin{array}{l}\text { Scale Mean if } \\
\text { Item Deleted }\end{array}$ & $\begin{array}{l}\text { Scale Variance } \\
\text { if Item Deleted }\end{array}$ & $\begin{array}{c}\text { Corrected Item- } \\
\text { Total } \\
\text { Correlation }\end{array}$ & $\begin{array}{l}\text { Squared } \\
\text { Multiple } \\
\text { Correlation }\end{array}$ & $\begin{array}{c}\text { Cronbach's } \\
\text { Alpha if Item } \\
\text { Deleted }\end{array}$ \\
\hline KKOI & 67.6906 & 65.661 & .659 & .497 & .860 \\
\hline KKO2 & 67.7250 & 67.259 & .562 & .399 & .864 \\
\hline KKO3 & 67.6389 & 66.546 & .585 & .419 & .863 \\
\hline KK04 & 67.9569 & 65.324 & .611 & .444 & .861 \\
\hline KK05 & 67.5201 & 68.037 & .462 & .304 & .867 \\
\hline KKO6 & 67.4742 & 67.468 & .451 & .293 & .867 \\
\hline KK07 & 68.0092 & 65.318 & .567 & .367 & .863 \\
\hline KK08 & 67.9323 & 65.787 & .543 & .340 & .864 \\
\hline KK09 & 67.3301 & 67.784 & .453 & .329 & .867 \\
\hline KK 10 & 67.7893 & 65.717 & .636 & .450 & .861 \\
\hline KK 14 & 69.6452 & 75.055 & -.029 & .100 & .900 \\
\hline KK16 & 67.7847 & 66.207 & .528 & .359 & .864 \\
\hline KK 18 & 67.8335 & 66.025 & .579 & .437 & .862 \\
\hline KK19 & 67.8347 & 65.650 & .624 & .460 & .861 \\
\hline KK20 & 67.7675 & 65.422 & .615 & .420 & .861 \\
\hline KK22 & 67.8180 & 65.642 & .573 & .391 & .862 \\
\hline KK23 & 68.2382 & 67.660 & .349 & .148 & .872 \\
\hline KK24 & 67.6676 & 67.705 & .390 & .218 & .869 \\
\hline KK25 & 67.8961 & 65.136 & .611 & .445 & .861 \\
\hline
\end{tabular}

Source: Primary Data, processed 2019.

Reliability Alpha Cronbach $=0,889$

$r$ tabel for 1.472 cases $=0,039$. 
Table 5. THE FIFTH STEP VALIDITY AND RELIABILITY TEST

\begin{tabular}{|c|c|c|c|c|c|}
\hline \multicolumn{6}{|c|}{ Item-Total Statistics } \\
\hline Items & $\begin{array}{l}\text { Scale Mean if } \\
\text { Item Deleted }\end{array}$ & $\begin{array}{c}\text { Scale } \\
\text { Variance if } \\
\text { Item Deleted }\end{array}$ & $\begin{array}{l}\text { Corrected } \\
\text { Item-Total } \\
\text { Correlation }\end{array}$ & $\begin{array}{l}\text { Squared } \\
\text { Multiple } \\
\text { Correlation }\end{array}$ & $\begin{array}{c}\text { Cronbach's } \\
\text { Alpha if Item } \\
\text { Deleted }\end{array}$ \\
\hline KKOI & 65.6940 & 66.719 & .660 & .497 & .892 \\
\hline KKO2 & 65.7285 & 68.178 & .578 & .396 & .894 \\
\hline KKO3 & 65.6424 & 67.513 & .595 & .419 & .894 \\
\hline KKO4 & 65.9604 & 66.470 & .605 & .442 & .893 \\
\hline KK05 & 65.5235 & 68.864 & .486 & .299 & .897 \\
\hline KKO6 & 65.4776 & 68.332 & .469 & .290 & .897 \\
\hline KKO7 & 66.0126 & 66.511 & .558 & .361 & .895 \\
\hline KK08 & 65.9357 & 66.810 & .547 & .340 & .895 \\
\hline KK09 & 65.3335 & 68.472 & .487 & .307 & .897 \\
\hline KK10 & 65.7928 & 66.739 & .641 & .450 & .892 \\
\hline KK16 & 65.7882 & 67.119 & .541 & .358 & .895 \\
\hline KK18 & 65.8370 & 67.013 & .587 & .437 & .894 \\
\hline KK19 & 65.8381 & 66.647 & .631 & .460 & .893 \\
\hline KK20 & 65.7710 & 66.467 & .617 & .419 & .893 \\
\hline KK22 & 65.8215 & 66.628 & .580 & .391 & .894 \\
\hline KK23 & 66.2417 & 68.843 & .344 & .146 & .903 \\
\hline KK24 & 65.6711 & 68.588 & .406 & .216 & .900 \\
\hline KK25 & 65.8995 & 66.201 & .612 & .445 & .893 \\
\hline
\end{tabular}

Source: Primary Data, processed 2019.

Reliability Alpha Cronbach $=0,903$

$r$ tabel for 1.472 cases $=0,039$. 
Table 6. "Kuesioner Kesiapan Kepemimpinan Mahasiswa" (Student"s Leadership Readiness Questionnaire $=S L R Q$ )

\begin{tabular}{|c|c|}
\hline \multicolumn{2}{|r|}{ DIMENSI I: MORAL \& PENGETAHUAN (Moral and Knowledge Dimension) } \\
\hline 1 & $\begin{array}{l}\text { Saya yakin bahwa saya mampu melaksanakan kepemimpinan secara efektif bagi } \\
\text { organisasi/institusi yang akan saya pimpin di masa mendatang. }\end{array}$ \\
\hline 2 & $\begin{array}{l}\text { Saya yakin bahwa saya akan dapat memahami kepribadian dan karakter anggota } \\
\text { organisasi/institusi yang saya pimpin. }\end{array}$ \\
\hline 3 & $\begin{array}{l}\text { Saya yakin bahwa saya sanggup berinteraksi dan bersosialisasi dengan semua lapisan } \\
\text { yang ada dalam organisasi/institusi yang saya pimpin. }\end{array}$ \\
\hline 4 & $\begin{array}{l}\text { Saya yakin bahwa saya memiliki kesiapan ilmu pengetahuan kepemimpinan yang } \\
\text { tinggi untuk menjadi pemimpin di masa depan. }\end{array}$ \\
\hline 5 & $\begin{array}{l}\text { Ketika saya berinteraksi dengan anggota organisasi yang saya pimpin, saya akan } \\
\text { memperhatikan bagaimana tanggapan dan perasaan mereka terhadap ucapan, } \\
\text { gerak-gerik, dan perilaku saya. }\end{array}$ \\
\hline 6 & $\begin{array}{l}\text { Saya mendapat ajaran moral yang kuat dari agama saya sebagai bekal untuk } \\
\text { menjadi pemimpin organisasi/institusi di masa depan. }\end{array}$ \\
\hline 7 & $\begin{array}{l}\text { Saya selalu meningkatkan kesiapan kepemimpinan saya dengan mengikuti } \\
\text { berbagai pelatihan kepemimpinan, baik di dalam maupun di luar kampus. }\end{array}$ \\
\hline 8 & $\begin{array}{l}\text { Saya siap menghadapi dan menyelesaikan apapun bila terjadi gejolak masa } \\
\text { (demo) yang dilakukan oleh para anggota organisasi/institusi yang saya pemimpin. }\end{array}$ \\
\hline 9 & $\begin{array}{l}\text { Saya selalu siap memberikan salam, senyum, hormat terhadap siapa saja yang saya } \\
\text { kenal dan saya temui di mana dan kapan saja. }\end{array}$ \\
\hline \multicolumn{2}{|r|}{ DIMENSI II: EMPATI \& PENGALAMAN (Empathy and ExperienceDimension) } \\
\hline 10 & $\begin{array}{l}\text { Saya yakin terhadap kompetensi dan kesanggupan saya untuk menjadi pemimpin } \\
\text { yang sukses dan sepenuh hati bagi organisasi/institusi di masa depan. }\end{array}$ \\
\hline 11 & $\begin{array}{l}\text { Saya tidak yakin bahwa ilmu pengetahuan, pemahaman, dan pelatihan tentang } \\
\text { kepemimpinan yang saya miliki akan bermanfaat ketika saya menghadapi dalam } \\
\text { situasi lingkungan } \\
\text { organisasional/institusional yang sangat kaostik (R). }\end{array}$ \\
\hline 12 & $\begin{array}{l}\text { Saya tidak hafal nama dan tidak kenal dengan para dosen di program studi tempat } \\
\text { saya belajar ini satu per satu (R). }\end{array}$ \\
\hline 13 & $\begin{array}{l}\text { Saya tidak memiliki pengalaman, pengetahuan, penguasaan, dan keterampilan } \\
\text { memimpin organisasi/institusi (R). }\end{array}$ \\
\hline 14 & $\begin{array}{l}\text { Saya berpendapat bahwa salam, senyum, sapa, dan hormat tidak ada manfaatnya } \\
\text { lagi bagi organisasi/institusi di era mendatang. }\end{array}$ \\
\hline 15 & $\begin{array}{l}\text { Saya tidak peduli terhadap kepribadian dan karakter anggota organisasi/institusi } \\
\text { yang akan saya pimpin }(R) \text {. }\end{array}$ \\
\hline 16 & $\begin{array}{l}\text { Saya yakin bahwa saya sanggup berinteraksi dan bersosialisasi dengan semua } \\
\text { lapisan yang ada dalam organisasi/institusi yang saya pimpin. }\end{array}$ \\
\hline 17 & $\begin{array}{l}\text { Ketika saya berada (bertugas atau berkunjung) di luar kampus, luar kota, luar } \\
\text { daerah, luar pulau, atau bahkan luar negeri, saya selalu merasa canggung untuk } \\
\text { berinteraksi dengan orang-orang lokal atau orang-orang yang baru saya kenal (R). }\end{array}$ \\
\hline
\end{tabular}


Tabel 6. Continued.

\begin{tabular}{|c|l|}
\hline DIMENSI III: HASRAT \& KETELADANAN (Passion and Exemplary Dimension) \\
\hline 18 & $\begin{array}{l}\text { Saya siap untuk menghadapi berbagai konflik yang mungkin akan terjadi dalam } \\
\text { organisasi/institusi yang akan saya pimpin. }\end{array}$ \\
\hline 19 & $\begin{array}{l}\text { Saya sanggup menjadi teladan bagi anggota organisasi/institusi yang akan saya } \\
\text { pimpin di masa depan. }\end{array}$ \\
\hline 20 & $\begin{array}{l}\text { Saya yakin bahwa mimpi (visi) kepemimpinan saya akan terwujud ketika saya } \\
\text { menjadi pemimpin organisasi/institusi di } \\
\text { masa depan. }\end{array}$ \\
\hline 21 & $\begin{array}{l}\text { Saya memiliki hasrat, atau keinginan yang kuat untuk menjadi pemimpin yang sukses } \\
\text { di masa mendatang. }\end{array}$ \\
\hline DIMENSI IV: KETERBUKAAN DAN PANGGILAN PERSONAL (Personal Openness and Mission \\
Dimension)
\end{tabular}

